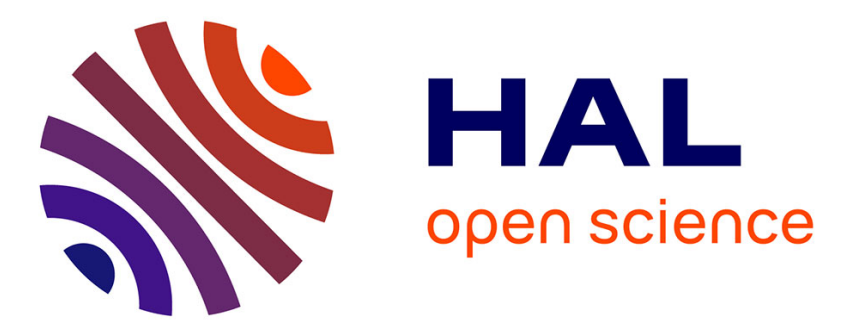

\title{
CHEMICAL VAPOUR DEPOSITION OF THE Al-O-N SYSTEM
}

B. Aspar, B. Armas, C. Combescure, D. Thenegal

\section{To cite this version:}

B. Aspar, B. Armas, C. Combescure, D. Thenegal. CHEMICAL VAPOUR DEPOSITION OF THE Al-O-N SYSTEM. Journal de Physique IV Proceedings, 1991, 02 (C2), pp.C2-665-C2-672. 10.1051/.jp4:1991280 . jpa-00249870

\section{HAL Id: jpa-00249870 https://hal.science/jpa-00249870}

Submitted on 1 Jan 1991

HAL is a multi-disciplinary open access archive for the deposit and dissemination of scientific research documents, whether they are published or not. The documents may come from teaching and research institutions in France or abroad, or from public or private research centers.
L'archive ouverte pluridisciplinaire HAL, est destinée au dépôt et à la diffusion de documents scientifiques de niveau recherche, publiés ou non, émanant des établissements d'enseignement et de recherche français ou étrangers, des laboratoires publics ou privés. 
Colloque C2, suppl. au Journal de Physique II, Vol. 1, septembre 1991

\title{
CHEMICAL VAPOUR DEPOSITION OF THE AI-O-N SYSTEM
}

\author{
B. ASPAR, B. ARMAS, C. COMBESCURE and D. THENEGAL \\ Institut de Science et de Génie des Matériaux et Procédés, \\ C.N.R.S, BP 5, F-66120 Font Romeu, Odeilio, France
}

\begin{abstract}
Using chemical vapour deposition, aluminium - oxygennitrogen coatings have been synthesized with aluminium trichloride, hydrogen, ammonia and nitrous oxide. The composition of the equilibrium phases is first determined by a thermodynamic calculation. The only AlON phase we investigate is (y) spinel aluminium oxynitride and it is considered as a stoichiometric phase with a composition of $\mathrm{Al}_{7} \mathrm{O}_{9} \mathrm{~N}$. The results indicate the existence fields of aluminium nitride and alumina and show the difficulty of obtaining the spinel aluminium oxynitride without other phases. Temperature, pressure and gas composition play an important part because they directly influence the reactivity of aluminium chloride. A hot-wall reactor is used for the experimental study. In this way, we obtain $A l N$, a mixture of $A I N$ and $\gamma \mathrm{AlON}$, and $\alpha \mathrm{Al}_{2} \mathrm{O}_{3}$. The annealed deposits show the stability of AlON obtained at 1270K.
\end{abstract}

\section{INTRODUCTION}

Aluminium - oxygen - nitrogen systems have many applications in electronics and as oxidation-resistant products. The range of applications can be increased using CVD, so we have investigated the AlON system using this process. $\mathrm{AlN} / 1 /$ and $\mathrm{Al}_{2} \mathrm{O}_{3}$ /2-3/ coatings have been synthesized with this process but those of AlON have not been studied extensively /4/. On the other hand, many studies of this system have been made with sintered materials $/ 5-7 /$. Thus, in the pseudobinary $\mathrm{AlN}-\mathrm{Al}_{2} \mathrm{O}_{3} \alpha$ three types of aluminium oxynitride are mentioned :

- In the AlN rich region, the polytypes of $A l N: 27 R, 21 \mathrm{R}, 12 \mathrm{H}$.

- The $y$ spinel aluminium oxynitride, a solid solution, present across the full width of the diagram above $1873 \mathrm{~K}$.

- $\delta$ quadratic aluminium oxynitride appears in the $\mathrm{Al}_{2} \mathrm{O}_{3}$-rich region of the diagram at high temperature.

We propose the synthesis of these materials using chemical vapour deposition with aluminium trichloride, ammonia, hydrogen and nitrous oxide.

\section{THERMODYNAMIC STUDY}

The composition of the equilibrium phases is first determined by a thermodynamic calculation. The equilibrium calculation is based upon the Gibbs free energy minimization method in a closed system. We used 
the "SOLGASMIX" program, developed by ERIKSSON $/ 8 /$, which calculates both vapour and solid phase compositions when equilibrium is reached at a given temperature and total pressure. The deposit can be considered as being in equilibrium with the vapour phase. It is assumed that the substrate is chemically inert with respect to the deposit and the vapour phase and that all the chemical species which can be present in equilibrium are known and taken into account in the calculations.

With our precursors, we consider the system : Al-Cl-H-O-N. Thus, 54 species are considered (table 1). The thermodynamic data used for the calculation is taken from JANAF /9/ tables. For the AlON system species, some assumptions have been made from the results of KAUFMAN $110 /$ and DORNER $/ 11 /$. Both determined that the $\gamma$ AlON phase is the only stable phase of the AlON system below $2150 \mathrm{~K}$ and considered that the spinel AlON phase is a stoichiometric phase with $\mathrm{Al}_{7} \mathrm{O}_{9} \mathrm{~N}$ composition. The difference between the Gibbs free energy of $\mathrm{Al}_{7} \mathrm{O}_{9} \mathrm{~N}$ formation determined by these two authors is insignificant above $1873 \mathrm{~K}$, but below this temperature the difference is important for evaluating the stability of AlON. In fact, DORNER's data projects AlON as unstable, whereas KAUFMAN's shows it to be stable at room temperature. We chose KAUFMAN's values because they are in better agreement with the experimental data.

Using the thermodynamic study, we can consider a large domain of investigation whose parameter limits are : $10^{-2} \leq \mathrm{N}_{2} \mathrm{O} / \mathrm{AlCl} \mathrm{Cl}_{3} \leq 100$, $0.15 \mathrm{NH}_{3} / \mathrm{AlCl}_{3} \leq 100$, os $\mathrm{H}_{2} / \mathrm{AlCl}_{3} \leq 25$, $1000 \mathrm{~T} \leq 1800 \mathrm{~K}, 1^{-3} \leq \mathrm{PSO} .05 \mathrm{Atm}$ (1015 P $55066 \mathrm{~Pa}$ ). The chemical species initially introduced into the calculations either react totally at equilibrium to give new species or remain partially unreacted. The results are formulated as thermodynamic yield $\eta_{x}$ defined as the ratio between the mole number of species $x$ and the mole number of the parent species, taking into account the stoichiometric coefficient. For example :

$\eta_{\mathrm{A} I N}=\frac{\mathrm{AlN} \text { eq }}{\mathrm{AlCl}_{3} \mathrm{In}} \quad \eta_{\mathrm{A} 1709 \mathrm{~N}}=7 \frac{\mathrm{Al}_{7} \mathrm{O}_{\text {eq }}}{\mathrm{AlCl}_{3} \mathrm{n}} \quad \eta_{\mathrm{HCl}}=\frac{\mathrm{HCl} \text { eq }}{3 \mathrm{AlCl}_{3} \mathrm{n}}$

in which $X_{i n}$ is the input number of moles of species $X$ $X$ eq is the number of moles of species $X$ at equilibrium.

2.1 Influence of the initial composition:

We look at the variation of $\eta_{x}$ as a function of the initial composition ratios : $\alpha=\mathrm{AlCl}_{3} / \mathrm{N}_{2} \mathrm{O}, \xi=\mathrm{NH}_{3} / \mathrm{AlCl} l_{3}, x=\mathrm{H}_{2} / \mathrm{AlCl}_{3}$.

a. Influence of the ammonia :

We investigate the influence of ammonia on the equilibrium composition without $\mathrm{N}_{2} \circ$ (figure 1 ). When $\xi$ increases, the quantity of solid AlN increases and consequently that of the chloride decreases. For a pressure of $0.05 \mathrm{Atm}$ and a temperature of $1400 \mathrm{~K}$, the aluminium chloride is predominantly in the form of $\mathrm{AlCl}_{3}$. For a lower pressure $P=10^{-3} \mathrm{Atm}$ ( $101 \mathrm{~Pa}$ - figure 2), with hydrogen present, the aluminium chloride is principally in the form of AlCl. Since this form is very stable under these conditions, it is necessary to have an excess of ammonia to start the formation of AlN. As in the previous case, the increase in the amount of ammonia induces a higher reactivity of the mixture and thus a higher yield of AlN.

b. Influence of nitrous oxide :

The results with $\xi=10, x=25$ are shown in figure 3 . We consider two ratios : $\alpha$ and $\alpha^{*}$ 
with $\alpha^{*}=\frac{\mathrm{AlCl}_{3} \text { in }-\left(\mathrm{AlCl}+\mathrm{AlCl} \mathrm{I}_{2}+\mathrm{AlCl} \mathrm{I}_{3}\right)_{\mathrm{eq}}}{\mathrm{N}_{2} \mathrm{O}_{\mathrm{in}}}$

- When $\alpha^{*}<<2 / 3$, there is an excess of oxygen and the species are in their most oxygenated state : $\mathrm{Al}_{2} \mathrm{O}_{3}, \mathrm{H}_{2} \mathrm{O}, \mathrm{O}_{2}$.

- When $\alpha^{*}<2 / 3$, we have to consider two cases :

$\alpha<2 / 3$ : all the aluminium chloride is converted to AlN

$\alpha>2 / 3$ : there is not enough oxygen to convert all the chloride to $\mathrm{Al}_{2} \mathrm{O}_{3}$, thus at equilibrium there is a mixture of $\mathrm{Al}_{2} \mathrm{O}_{3}$ and aluminium chloride which is mainly in the form of $\mathrm{AlCl}_{3}$.

- When $\alpha^{*}>2 / 3$, a less oxygenated phase emerges : $A 1_{7} O_{9} N$. This is because the maximum quantity of aluminium chloride stable under these conditions has been reached. Thus, for $7 / 9>\alpha^{*}>2 / 3$, we have a mixture of $\mathrm{Al}_{7} \mathrm{O}_{9} \mathrm{~N}$ and $\mathrm{Al}_{2} \mathrm{O}_{3}$.

- When $\alpha^{*}=7 / 9$, we have pure $\mathrm{Al}_{7} \mathrm{O}_{9} \mathrm{~N}$.

- When $\alpha^{*}>2 / 3$, there is insufficient oxygen to form pure $A l_{7} O_{9} N$ and the excess of nitrogen leads to the emergence of AlN.

$\frac{\text { c. Influence of hydrogen : }}{A \text { comparison between }}$

importance of hydrogen. Hydrogen facilitates the reduction of the $\mathrm{AlCl}_{3}$ present. Consequently, if some $\mathrm{AlCl}_{3}$ remains at equilibrium, when the quantity of hydrogen augments, that of $\mathrm{AlCl}_{3}$ diminishes and thus more AlN is produced.

\subsection{Influence of pressure :}

For a lower pressure $P=10^{-3}$ Atm ( $P=101 \mathrm{~Pa}$ - figure 5), when $\alpha>2 / 3$, the quantity of aluminium chlorides increases. Thus the yield of solid phase $\mathrm{AlN}$ or $\mathrm{Al}_{7} \mathrm{O}_{9} \mathrm{~N}$ decreases. Furthermore, under these conditions, the aluminium chloride is mainly in the form of AlCl.

\subsection{Influence of the temperature :}

The temperature directly influences the stability of the different chlorides. Thus at low temperature, the aluminium chloride is in the form of $\mathrm{AlCl}_{3}$, but at high temperature ( $T>1600 \mathrm{~K}$ ) the majority is in the form of AlC1 (Figure 6). Additionally a rise in temperature leads to an increase in the total quantity of aluminium chlorides present. So, for a given $\alpha$, as the quantity of $\mathrm{AlCl}-\mathrm{AlCl}_{2}-\mathrm{AlCl}_{3}$ increases, $\alpha^{*}$ decreases. Figure 6 shows different stages as $\alpha^{*}$ decreases.

We still have : $\alpha^{*}<2 / 3$

$$
\begin{array}{ll}
\alpha^{*}<2 / 3 & \rightarrow \mathrm{Al}_{2} \mathrm{O}_{3} \alpha \\
7 / 9>\alpha^{*}>2 / 3 & \rightarrow \mathrm{Al}_{2} \mathrm{O}_{3} \alpha+\mathrm{Al}_{7} \mathrm{O}_{9} \mathrm{~N} \\
\alpha^{*}>7 / 9 & \rightarrow \mathrm{Al}_{7} \mathrm{O}_{9} \mathrm{~N}+\mathrm{AlN} .
\end{array}
$$

\section{EXPERIMENTAL STUDY :}

The experimental device used is a vertical hot wall reactor composed of a graphite susceptor heated by high frequency induction. Source gases were hydrogen, ammonia, nitrous oxide and nitrogen. The aluminium chloride, put in an evaporator, was heated by a wire heater and carried by nitrogen. The aluminium chloride was inputted separately from the other reactive gases to avoid a reaction between them before the reaction zone. A graphite sample protected by a $\beta$ SiC layer deposited by CVD was used as substrate.

\subsection{Aluminium nitride}

We started our investigations at $\mathrm{T}=1270 \mathrm{~K}$ and $\mathrm{P}=130 \mathrm{~Pa}$ without the presence of $\mathrm{N}_{2} \mathrm{O}$. Using quantities of $\mathrm{NH}_{3}$ consistent with the thermodynamic study, we obtained homogeneous coatings of AlN. The $X$-ray diffraction pattern shows very well crystallised AIN (figure 7a) 
Scanning Electron Microscope (SEM) observations of the cross section reveal two zones of the AlN layer, the first dense and the second porous (figure 8 ). We also see good adherence between substrate and coating. Wavelength Dispersive System (WDS) analysis indicates that with $A 1$ and $N$ there is less than $2 \%$ oxygen present.

We investigated the influence of temperature on the coatings. For a temperature of $1050 \mathrm{~K}$ the coatings are less crystallised than those obtained at $1270 \mathrm{~K}$. In fact, broadened peaks are observed on the $\mathrm{x}$-ray diffraction pattern.

\subsection{Aluminium oxynitride}

We introduced nitrous oxide into the reaction gas mixture. All the following studies were done with $T=1270 \mathrm{~K}$ and $\mathrm{P}=130 \mathrm{~Pa}$. In presence of ammonia and hydrogen and when $\mathrm{N}_{2} \mathrm{O} / \mathrm{AlCl}_{3}>50$, we obtained homogeneous coatings. $x$-ray diffraction patterns indicate the emergence of $y$ aluminium oxynitride : more precisely, there is a mixture of $y$ AloN and AIN (figure 7b). To verify the existence of $\gamma$ AlON as opposed to $Y \mathrm{Al}_{2} \mathrm{O}_{3}$, it was necessary to anneal the coatings - annealing transforms $\vee \mathrm{Al}_{2} \mathrm{O}_{3}$ into $\alpha \mathrm{Al}_{2} \mathrm{O}_{3}$. Thus, we annealed all coatings at $1400 \mathrm{~K}$ under $7.10^{4} \mathrm{~Pa}$ of nitrogen for 2h30. The X-Ray diffraction pattern of the annealed coatings shows well-defined peaks of $V$ AlON. Our coatings are thus stable.

The quantity of each phase of the mixture can be evaluated approximately from the ratio of the heights of the peaks corresponding to the two phases on the X-ray pattern. So, when $\mathrm{N}_{2} \mathrm{O} / \mathrm{AlCl}_{3}$ increases, the quantity of $y$ AlON is higher. WDS analysis confirms this phenomenon. The quantity of oxygen in the coatings is proportional to that of $\mathrm{N}_{2} \mathrm{O}$ input. SEM observations show a dense layer and good adherence to the substrate (figure 9 ).

With a large excess of $\mathrm{N}_{2} \mathrm{O}$, we obtained homogeneous and compact coatings. $X$-ray diffraction patterns indicate that there is a mixture of $\alpha \mathrm{Al}_{2} \mathrm{O}_{3}$ and $\mathrm{Y} \mathrm{AlON}$.

\subsection{Alumina}

Without ammonia, in the presence of hydrogen and with $\mathrm{N}_{2} \mathrm{O} / \mathrm{AlCl}_{3}=35, \mathrm{~T}=1270 \mathrm{~K}$ and $\mathrm{P}=130 \mathrm{~Pa}$, we obtain a homogeneous deposit of well-crystallised $\alpha$ alumina (figure 7c). SEM observations indicate a non-porous coating and good adherence to the SiC (figure 10).

\section{CONCLUSION}

In the experimental study, by varying the quantity of ammonia and nitrous oxide, we have sampled the entire Al-O-N system. Consequently, we have synthesized AlN, a mixture of $A I N$ and $\gamma A I O N$, a mixture of $\gamma$ AION and $\alpha \mathrm{Al}_{2} \mathrm{O}_{3}$, and $\alpha \mathrm{Al}_{2} \mathrm{O}_{3}$.

This study indicates that spinel AlON can be obtained at $1270 \mathrm{~K}$, using chemical vapour deposition, and that these coatings are stable after being annealed at $1400 \mathrm{~K}$.

These results are in agreement with the thermodynamic study which indicates the existence of $\mathrm{AlN}$ and $\mathrm{Al}_{2} \mathrm{O}_{3}$ and shows the difficulty of obtaining $y$ AlON alone.

The results are the first in our study of the Al-O-N system using $\mathrm{AlCl}_{3}, \mathrm{NH}_{3}$ and $\mathrm{N}_{2} \mathrm{O}$. We are continuing to investigate it under various conditions. The coatings are being characterised further with Auger spectroscopy and with transmission electron microscopy to examine the interface between the coating and substrate. 


\section{ACKNOWLEDGMENTS}

This work has been supported by AEROSPATIALE - Division Systèmes Stratégiques et Spatiaux - F33165 SAINT-MEDARD-EN-JALLES.

\section{REFERENCES}

/1/PAUleAu Y, haNTZPERGUE J.J, REMY J.C, Bull.Soc.Chim.France $n^{\circ}$ 5-6 (1979) 199-214.

/2/HALL LOu, ROBINETTE Bill, Second Int.Conf.Chem.Vap.Dep., (1970) Ed J.M. Blocher Jr. 637-649.

/3/COLMET R, NASLAIN R, and HAGENMULLER P., J.of Elect.Chem.Soc. $129, n^{\circ} 6$ (1982) 1367-1372.

/4/SILVESTRI V.J, IRENE E.A, ZIRINSKY S. and KUPTSIS J.D, J. of Electronic Mat., 4, $n^{\circ} 3$ (1975) 409-427.

/5/LEJUS A.M. Thèse, Rev. int. Hautes Tempér. et Réfract. $n^{\circ} 1$ (1964) 53-95.

/6/MC CAULEY J.W, CORBIN N.D, J.Amer.Cer.Soc., 62, n9-10 (1979) $476-479$.

/7/CORBIN N.D, Aluminum oxynitride spinel, July 1987 US Army Materials technology Laboratory, Watertown, Massachussets 021720001.

/8/ERIKSSON G., Chemica Scripta, 8 (1975) 100-103.

19/CHASE N.W, Jr DAVIE C.A, DOWNEY J.R, FRURIP D.J, MC DONALD R.A SYVERUD A.N ; JANAF Thermochemical Tables, Third Edition

J.of Phys.and Chem.reference Data, 14 (1985).

/10/KAUFMAN L. , Calculation of Quasibinary and Quasiquaternary Oxynitride Systems - III - Presented at CALPHAD 8, Calphad 3 $n^{\circ} 4$ (1979) 275-291.

/11/DORNER P., GAUCKLER L.J, KRIEG H, LUKAS H.L, PETZOW G, WEISS J, J. of Mater. Science, 16 (1981) 935-943.

Table 1 : Chemical species introduced in the thermodynamic calculations ( $<$ solid, // liquid, gas).

\begin{tabular}{|c|c|c|}
\hline & SYSTEM & \\
\hline $\begin{array}{l}\mathrm{Al} \\
\mathrm{AlCl} \\
\mathrm{AlCl}_{2} \\
\mathrm{AlCl}_{2} \\
\mathrm{Al}_{2} \mathrm{Cl}_{6} \\
\mathrm{AlOCl} \\
\mathrm{AlH} \\
\mathrm{AlOH} \\
\mathrm{AlOOH} \\
\mathrm{AlO} \\
\mathrm{AlO}_{2} \\
\mathrm{Al}_{2} \mathrm{O} \\
\mathrm{Al}_{2} \mathrm{O}_{2} \\
\mathrm{Cl} \\
\mathrm{Cl}_{2} \\
\mathrm{ClO} \\
\mathrm{ClO}_{2} \\
\mathrm{Cl}_{2} \mathrm{O}\end{array}$ & $\begin{array}{l}\mathrm{ClHO} \\
\mathrm{ClNO} \\
\mathrm{ClNO} \\
\mathrm{N} \\
\mathrm{N}_{2} \\
\mathrm{NH} \\
\mathrm{NH}_{2} \\
\mathrm{NH}_{3} \\
\mathrm{~N}_{2} \mathrm{H}_{2} \\
\mathrm{~N}_{2} \mathrm{H}_{4} \\
\mathrm{NO}_{4} \\
\mathrm{NO}_{2} \\
\mathrm{NO}_{3} \\
\mathrm{~N}_{2} \mathrm{O} \\
\mathrm{N}_{2} \mathrm{O}_{3} \\
\mathrm{~N}_{2} \mathrm{O}_{4} \\
\mathrm{~N}_{2} \mathrm{O}_{5} \\
\mathrm{NOH}\end{array}$ & $\begin{array}{l}\mathrm{NO}_{2} \mathrm{H} \\
\mathrm{NO}_{3} \mathrm{H} \\
\mathrm{H} \\
\mathrm{H}_{2} \\
\mathrm{H}_{2} \mathrm{O} \\
\mathrm{H}_{2} \mathrm{O}_{2} \\
\mathrm{HO} \\
\mathrm{HO}_{2} \\
\mathrm{O} \\
\mathrm{O}_{2} \\
/ \mathrm{Al} / \\
\langle\mathrm{AlN}\rangle \\
\left\langle\mathrm{Al} \mathrm{O}_{3}\right\rangle \\
\left\langle\mathrm{Al}_{7} \mathrm{O}_{9} \mathrm{~N}\right\rangle \\
\left\langle\mathrm{AlCl}_{3}\right\rangle \\
\langle\mathrm{AlOCl} \mathrm{OCl}\rangle \\
\left\langle\mathrm{NH}_{4} \mathrm{Cl}\right\rangle \\
\left\langle\mathrm{NH}_{4} \mathrm{ClO}_{4}\right\rangle\end{array}$ \\
\hline
\end{tabular}



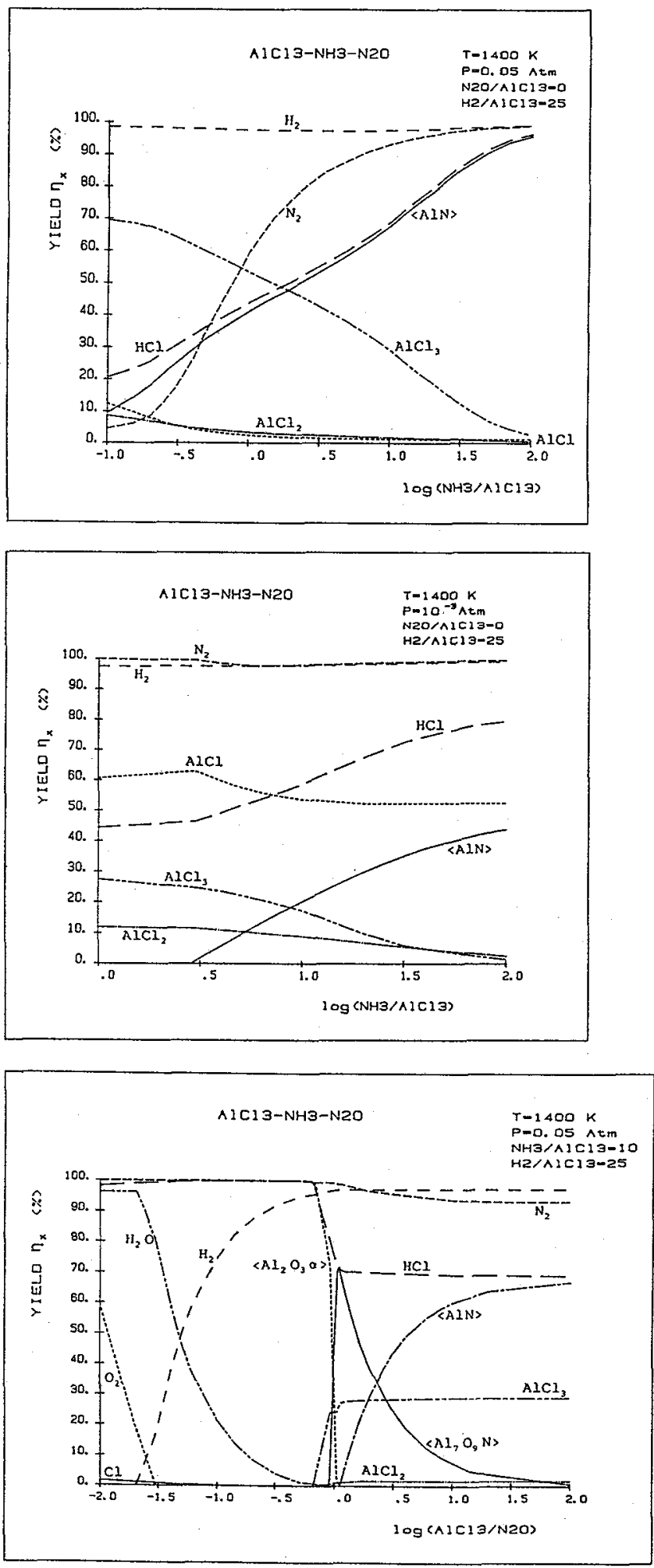

Figure 1:

Variation of $\eta_{\mathrm{x}}$ equilibrium yields for the main species as a function of $\xi$ with $x=25, P=0.05$ Atm $(5066 \mathrm{~Pa})$, $\mathrm{T}=1400 \mathrm{~K}$.

Figure 2 :

Variation of $\eta_{\mathrm{x}}$ equilibrium yields for the main species as a function of $\xi$ with $x=25, P=10^{-3}$ Atm (101 Pa), $\mathrm{T}=1400 \mathrm{~K}$.

Figure 3 :

Variation of $\eta_{x}$ equilibrium yields for the main species as a function of $\alpha$, with $\xi=10, \quad k=25, \quad P=0.05 \quad$ Atm $(5066 \mathrm{~Pa}), \mathrm{T}=1400 \mathrm{~K}$. 


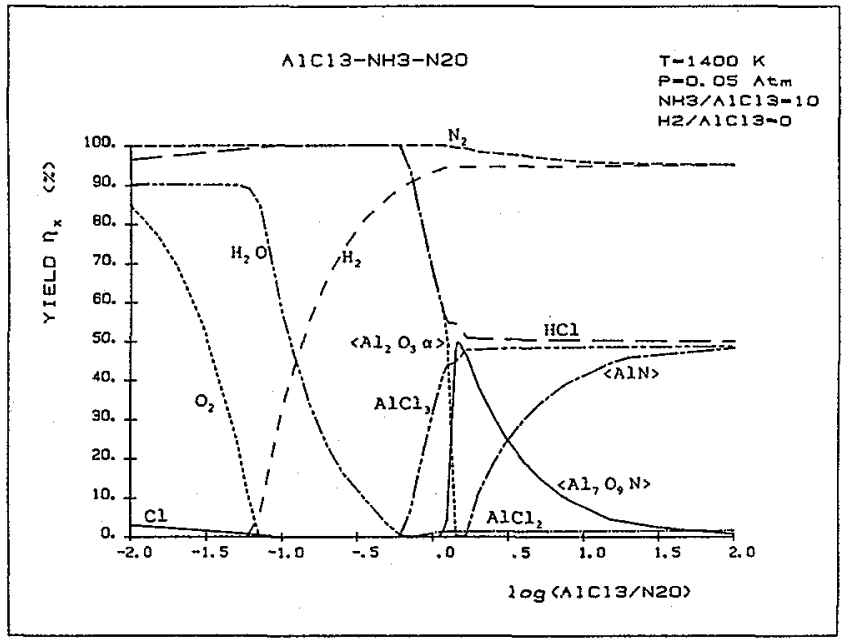

Figure 4 :

Variation of $\eta_{x}$ equilibrium yields for the main species as a function of $\alpha$, with $\xi=10, \quad x=0, \quad P=0.05 \quad$ Atm $(5066 \mathrm{~Pa}), \mathrm{T}=1400 \mathrm{~K}$.

Figure 5 :

Variation of $\eta_{x}$ equilibrium yields for the main species as a function of $\alpha$, with $\xi=10, \quad x=25, \quad P=10^{-3} \quad$ Atm (101. Pa), $T=1400 \mathrm{~K}$.

Figure 6 :

Variation of $\eta_{x}$ equilibrium yields for the main species as a function of temperature with $\alpha=2, \quad \xi=10, \quad x=25$, $\mathrm{P}=10^{-3}$ Atm (101 Pa), $\mathrm{T}=1400 \mathrm{~K}$. 


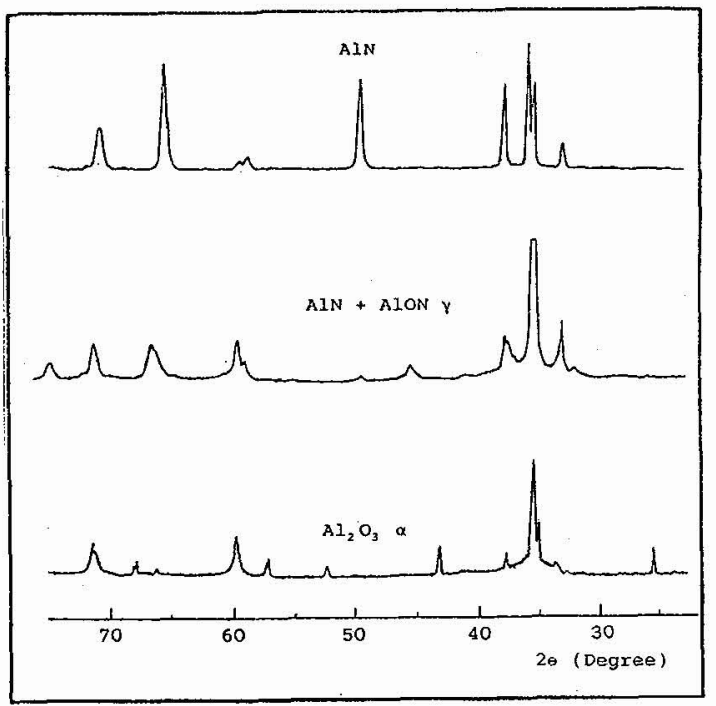

Figure 7 :

$x$-ray diffraction pattern of AlN (7a), $A I N$ and $Y$ AION (7b), $\alpha \mathrm{Al}_{2} \mathrm{O}_{3}(7 \mathrm{c})$.

Because the different deposits are not thick $(<10 \mu \mathrm{m})$, the peaks corresponding to the substrate (SiC) are present.

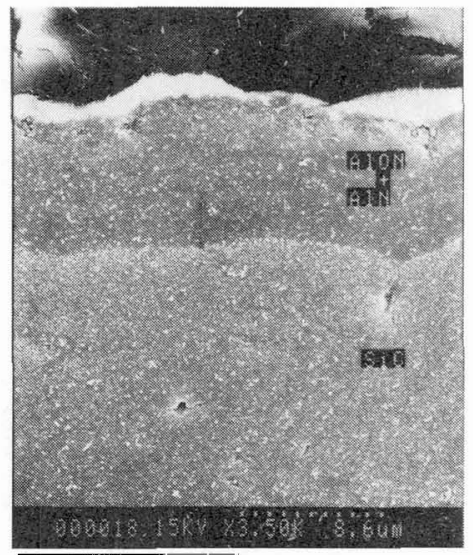

Figure 9 :

SEM micrograph of a cross-section of a mixture of $A 1 N$ and $Y$ AION $(T=1270 \mathrm{~K}$, $\mathrm{P}=130 \mathrm{~Pa}$ ).

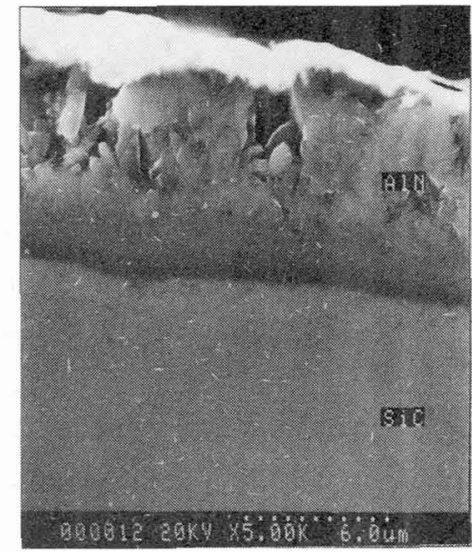

Figure 8 : SEM micrograph of a cross-section of $\mathrm{AIN}(\mathrm{T}=1270 \mathrm{~K}, \mathrm{P}=130 \mathrm{~Pa}$, $\left.D_{N 20}=0 \mathrm{cc} / \mathrm{min}\right)$.

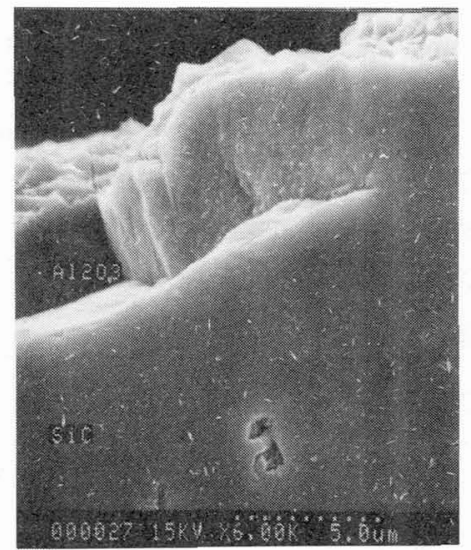

Figure 10 :

SEM micrograph of a cross-section of a $\mathrm{Al}_{2} \mathrm{O}_{3}(\mathrm{P}=130 \mathrm{~Pa}, \mathrm{~T}=1270 \mathrm{~K}$, $D_{N_{K} 3}=0 \mathrm{co} / \mathrm{min}$ ). 